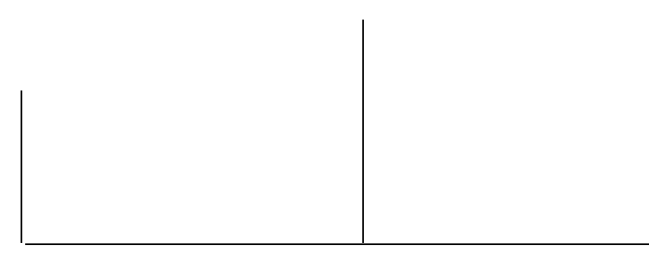

Rev. Latinoam. Psicopat. Fund., VI, 3, 94-109

\title{
Violência e transgressão: interrogando a adolescência*
}

Isabel da Silva Kahn Marin

\begin{abstract}
Este artigo discute como a compreensão do processo de subjetivação do adolescente traz elementos preciosos para a problematização da transgressão e da violência que, por sua vez, são condição para a constituição subjetiva, bem como fatores de transformação ou manutenção da ordem social.
\end{abstract}

Palavras-chave: Violência, transgressão, adolescência, pulsão, psicanálise, psicopatologia fundamental

* Texto apresentado, originalmente, na Mesa-redonda "Violência e transgressão" no VI Congresso Brasileiro de Psicopatologia Fundamental realizado em Recife, setembro de 2002. 


\section{Introdução \\ “O Adolescente bandido" interpela o psicanalista}

Ao me terem falado sobre sua juventude, momentos antes da puberdade, pessoas que, mais tarde, freqüentemente se tornaram muito respeitáveis, me informaram sobre ações proibidas que praticaram naquele período - tais como furto, fraudes e até mesmo incêndio voluntário. Eu tinha o hábito de me descartar dessas declarações com o comentário de que estamos familiarizados com a fraqueza das inibições morais daquele período de vida e não fazia qualquer tentativa para localizá-las em um contexto mais importante. (Freud, 1916, p. 347)

Como entender que essa atitude compreensiva de Freud ao falar da puberdade, no início do século XX, não contribua para derrubar os fortes argumentos que encontramos hoje no Brasil, para a redução da idade penal? É preocupante também a forma como os telejornais apresentam os crimes praticados por jovens, numa clara apologia ao seu grau de perversidade, clamando para que sejam julgados e punidos como os adultos o são. Esses argumentos se apóiam nas estatísticas sobre o aumento da criminalidade entre os jovens nesta última década, muito embora pareçam desconsiderar o significativo aumento de crianças e jovens assassinados no Brasil nesse mesmo período (48\%), segundo pesquisas divulgadas pela Unesco, em 2002 (Folha de S. Paulo, 4/5/2002).

Penso que o psicanalista não deva se furtar a pensar e se manifestar frente aos fenômenos sociais, políticos e culturais, principalmente quando a dignidade humana está ameaçada. Freud nos apontou esse caminho, ensinando-nos como a palavra recalcada está intimamente vinculada à violência e à dor. É nessa perspectiva que nos convida a refletir sobre o fato de que: "Tudo 


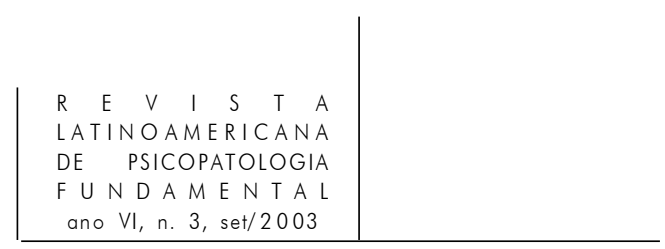

que estimula o crescimento da civilização, trabalha simultaneamente contra a guerra" ( 1933, p. 208).

Por isso proponho neste artigo discutir como a compreensão do processo de subjetivação do adolescente, traz elementos preciosos para a problematização da transgressão e da violência que são condição para a constituição subjetiva, bem como fatores de transformação ou manutenção da ordem social.

\section{Violência, transgressão, pulsão: manifestações do pathos. Condições para subjetivação}

Este questionamento se faz a partir da posição da Psicopatologia Fundamental que

... está interessada num sujeito trágico que é constituído e coincide com o pathos... O que se figura na tragédia é pathos que, no sentido clássico, quer dizer tudo o que se fez ou que acontece de novo, do ponto de vista daquele ao qual acontece. Nesse sentido, quando pathos acontece, algo da ordem do excesso, da desmesura, se põe em marcha, sem que o eu possa se assenhorear desse acontecimento, a não ser como paciente, como ator. (Berlinck, 1998, p. 53)

Ora, encontramos no sentido primeiro da palavra violência a idéia de "irrupção de uma força intensa que deixa o sujeito submisso aos efeitos dessa força sem que ele possa se livrar dela" (Toubiana, 1997, p. 167). Essa concepção retoma, no fundo, a etimologia do termo violência, que vem do latim, em que vis quer dizer a força. Aliás, Jean Bergeret pesquisa cuidadosamente o termo demonstrando que na origem apresenta a idéia de vida sem a conotação destrutiva ou erótica e com a qual estamos familiarizados (Bergeret, 1995). Violência apresenta também na língua portuguesa um caráter polissêmico, que compreende desde a noção de ação violenta até a idéia de impetuosidade ou veemência, passando pelas noções de constrangimento, ou contrariar as normas, violar, etc.

$\mathrm{O}$ mesmo se dá com o termo transgressão. Nos dicionários Aurélio e Larousse Cultural encontramos: "1. Ato ou efeito de transgredir, infração, violação - sendo que no verbete transgredir, aparece a definição de passar além, infringir, atravessar, violar uma norma 2. (Geol.) Invasão do mar que acarreta a formação de depósitos marinhos onde dantes era continente, provocando transformações na costa litorânea". Portanto, analisando esses termos, depara-se com sua polissemia e a extensão de seus significados traz uma situação paradoxal a qual psicanalistas estamos habituados a escutar. Criação ou destruição: do que se tratam as transgressões? Do que se tratam as violentas manifestações juvenis? 


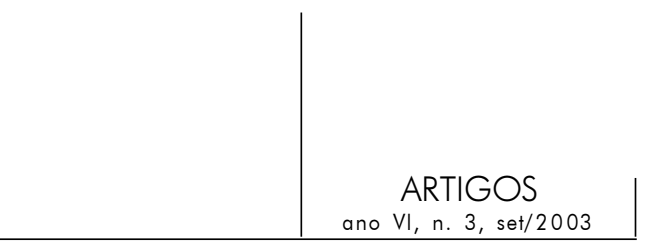

Enriquez, a partir de Canguilhem, tece reflexões importantes para fundamentar essas questões.

"A vida é constituída de todas as forças que se opõem à morte" (Canguilhem, 1943). Em outras palavras o ser humano luta contra a entropia que espreita constantemente o mundo físico e o mundo vivo, e é criador de neguentropia. Ela torna presente o "querer viver" schopenhaueriano e nietzschiano, e a vitória da pulsão de vida sobre a pulsão de morte. Mesmo quando está misturada com algum pathos (de sofrimento), e se às vezes se desvia no patético, ela faz surgir novos valores, pois o homem, como diz Nietzsche "uma coisa que pode ser superada" e, acrescentemos, a única que tem essa característica (...) Assim, como escreveu Bataille (1975), "a transgressão não é a negação da proibição, ela a ultrapassa e a completa". (Enriquez, 2002, p. 122-3)

Isto posto, retomemos da tradição psicanalítica o conceito fundamental de pulsão - Trieb. Como aponta Luís Hanns

... Trieb, tal qual é usado em alemão, entrelaça quatro momentos que conduzem do geral ao singular. Abarca um princípio maior que rege os seres viventes e que se manifesta como força que coloca em ação os seres de cada espécie; que aparece fisiologicamente "no" corpo somático do sujeito como se brotasse dele e o aguilhoasse; e por fim, que se manifesta "para" o sujeito fazendo-se representar ao nível interno e íntimo como se fosse sua vontade ou um imperativo pessoal. No texto freudiano também a palavra mantém essas características de uso. Trieb evoca a idéia de força poderosa e irresistível que impele. (Hanns, 1996, p. 338)

Radmila Zygouris (1999) comenta: “A pulsão em sua origem não é, portanto, nem boa nem má, ela só procura satisfação: é apenas devido à inadequação do objeto e impotência do sujeito em encontrar o objeto adequado que ela se torna destruidora do objeto tanto quanto do sujeito, tentando manter um estado de menor tensão" (p. 15). Diz ainda a autora: "Desejar, falar, pensar, sonhar, fazer. Tudo isto implica nas pulsões de vida, implica no ato de se estar frente a frente com um outro, de ir em direção ao outro e abre um caminho para estabelecer uma relação com o outro, uma relação de objeto, como é chamada" (p. 25).

No entanto, observa-se o quanto tem sido difícil, nos dias de hoje, a disponibilidade dos sujeitos em se fazerem "objetos" e enfrentarem essa violência do movimento pulsional, chegando a abandonar seus parceiros significativos (filhos, cônjuges, alunos, etc.) à solidão e ao desamparo. "O ato de crueldade é seu último avatar (do Jogo Pulsional - Eros e Tânatos), última tentativa de um fazer erótico, de um ir em direção ao outro, nem que seja para destruí-lo; quando na falta desse outro inacessível, o 'eu' tornado impotente, se abraça a si próprio num último gesto de potência” (Ibid., p. 25). 


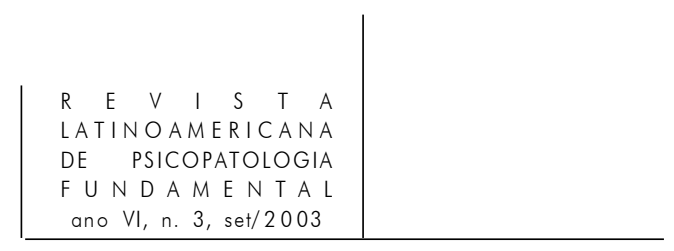

A proposta da Psicopatologia Fundamental, na tradição do método clínico, "busca uma classificação compreensiva tão exclusiva que se confunde com a própria subjetividade de cada um" (Berlinck, s/d, p. 11). Essa compreensão, como apontamos, na sua dimensão trágica, aproxima-se justamente do caráter violento que a emergência do sujeito, ou seja, que a expressão subjetiva apresenta.

\section{A adolescência e o drama da subjetivação}

$\mathrm{Na}$ perspectiva da análise proposta pode-se dizer que o processo de subjetivação sempre retoma a questão desesperada do sujeito de se fazer único e de ser reconhecido pelo mundo.

Nada melhor que a adolescência para nos lembrar disso. Propõe-se assim considerar o adolescente o paradigma do sujeito humano, ou seja, do drama de sua subjetivação - como colocar-se na rede social mantendo singularidade e autonomia; ou, dito de outra forma, nas palavras de P. Jeammet, "o paradoxo chave do desenvolvimento humano - aquele da necessidade de conciliar a necessidade fundamental de identificação e de se alimentar dos objetos investidos, com a necessidade de salvaguardar a autonomia narcísica" (1995, p. 89). Penso que é por isso que o adolescente incomoda: ele retoma dia-a-dia nosso conflito essencial. Ele luta, não desiste; busca sempre transgredir e por isso expõe nossa violência recalcada.

Renúncia narcísica, vicissitudes edípicas, parecem ser um tema tão banal em psicanálise, mas por que ele persiste? O tema violência e a questão do adolescente que hoje se articulam tão fortemente na sociedade - e que a psicanálise não pode se furtar a entender -, retomam sem dúvida esse drama fundante do humano: "A gestão de sua violência interna, seus votos incestuosos e parricidas, de sua agressividade legítima e estruturante, assim como às expressões problemáticas de suas pulsões de morte" (Birraux, 1997, p. 132, tradução minha).

É na adolescência, sabemos, o momento de romper, decididamente, com o ideal narcísico dos pais, constituindo, para além de suas determinações, a possibilidade de um ideal de Eu. Ou seja, é momento de subjetivar-se, aceitando as limitações sociais, posicionando-se criativamente. É tempo de buscar, em novas relações, recuperar "amores perdidos", fundar-se num corpo que foi amado e que poderá amar, que foi gerado e poderá gerar, enfim, de entrar na realidade social, simbólica, com nome próprio. Esse processo, porém, não é feito sem luta, sem transgressões. Pensemos na explosão pulsional que um corpo em puberdade significa. Pensemos na multiplicidade de opções de identificação, de ilusões imaginárias que a sociedade contemporânea coloca para que um jovem 


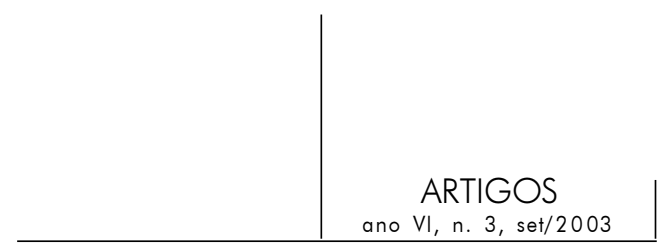

se posicione, estabelecendo-se assim um excesso de exigências, muito embora sob a forma de promessas de prazer e realização.

A antropologia nos mostra que a adolescência é associada à violência entre inúmeros povos em todos os continentes. Rituais iniciáticos de sociedades ditas primitivas, pela passagem da infância para a idade adulta, testemunham a necessidade do controle violento sobre a impetuosidade da puberdade; talvez por esses jovens, ao representarem "mudança", serem vistos como portadores do risco de desorganização social. A cultura impõe sua ordem e os sujeitos devem a ela se submeter - todo ritual é uma forma de violência e pode deixar marcas corporais dolorosas que testemunham a passagem do mundo da infância para o mundo adulto.

Enriquez (1999) comenta que a obrigação do sofrimento para inscrever a sociedade no corpo não significa "Não terás o desejo de poder" e sim "Não te revoltarás, aceitarás a lei do pai (...) deves tornar-te um ser para sempre submisso, que não deve mais ser inovador (como na época em que eras jovem e louco), que não pode ser portador da discórdia. E, um dia, tu também, nesta condição, poderás fazer outros sofrerem. Sofrer é então, aceitar não mais rivalizar com o pai, é aceitar no corpo a marca da castração simbólica, sofrer é entrar no mundo de submissão e de dominação (...). Tornar-se homem é entrar nas relações assimétricas", conclui Enriquez (p. 210-1).

A condição para tornar-se homem, analisada por Enriquez, parece absurda na contemporaneidade, onde impera o narcisismo e o princípio do prazer é praticamente um regulador social. ${ }^{1}$ Sendo assim a idéia de sofrer é anacrônica e a sensação de submissão intolerável. Como o jovem irá então se situar em nossa sociedade? Como será reconhecido e acolhido? Numa sociedade que parece valorizar tanto a infância e a juventude, o que significa a adesão à proposta de encarcerá-los precocemente?

Poder-se-ia analisar que se trata de uma projeção de nossa violência sobre uma classe social menos favorecida, para quem a única possibilidade de reconhecimento numa sociedade que a exclui cotidianamente é retornar com violência. Nessa perspectiva é possível entender seguindo a tradição winnicotiana, a delinquiência como mecanismo de denúncia social: afirmação do Eu, a busca do mundo que foi perdido, rompido abrupta e arbitrariamente. Se pensarmos na sociedade contemporânea que acena com promessas de consumo ilimitadas e de prazer imediato, o ato delinqüencial não deixa de ser a denúncia de uma

1. Maiores detalhamentos sobre as características da contemporaneidade não são possíveis no âmbito deste trabalho, mas desenvolvo essas idéias no livro Violências. 


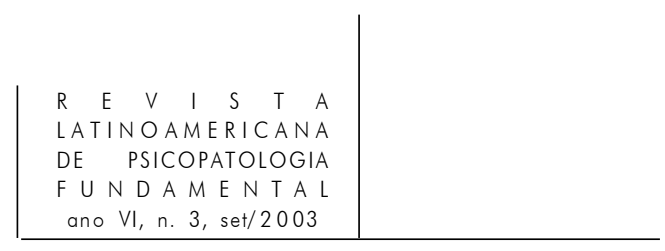

impostura. Nesse ponto as classes sociais menos privilegiadas encontram uma desvantagem. ${ }^{2}$ Mas será que basta esta explicação? Sabemos que não, pois várias pesquisas indicam ter aumentado o número de adolescentes "em conflito com a lei", ${ }^{3}$ provenientes de famílias da classe média e de cor branca. Basta ver também os noticiários para se perceber o número crescente de crimes realizados por jovens de classe média, não só no Brasil como em todo o mundo.

\section{O adolescente espelhando o ideal social: afirmação narcísica}

Considerando então esse cenário, entende-se que na sociedade contemporânea, com o triunfo do individualismo e o império do narcisismo, resta ao jovem expressar de forma radical a tentativa de apagar a ferida narcísica, cumprindo a promessa do imaginário social narcísico, ou seja, apagar os vestígios do outro, portador de um desejo próprio.

Freud (1915), ao afirmar que o Eu só advém na alteridade, e que o outro é o primeiro inimigo do eu, nos permite pensar que o ato violento, paradoxalmente, convoca o outro. Uma forma de manter o objeto vivo seria atacá-lo. Por isso mesmo é fundamental o posicionamento do adulto frente ao jovem. Senão se está lançado no desamparo. Isso porque podemos dizer que

... a violência surge aí onde se experimenta o insuportável indizível: aí onde o pensamento e as palavras faltam para dizer o sofrimento, ou simbolizá-lo. Aí onde a ameaça fantasmática do sucumbir narcísico força a que se faça mal ao mundo exterior. Não há violência que não se origine de um terrível sofrimento, quando saem de cena as forças de ligação em benefício da Pulsão de Morte. (Birraux, 1997, p. 138)

Quando faltam o suporte e as palavras adequadas às manifestações pulsionais, desde as origens do sujeito, ou seja, a violência primária, conforme Piera Aulagnier discute, a violência em ato pode ser entendida como resposta defensiva à violência pulsional, ou seja, a sua projeção. Não deixa de ser um grito que convoca o outro que falhou, o objeto amado/odiado que não pôde suportá-lo e interpretá-lo.

Simone Couraud, no seu trabalho "L'acte criminel à l'adolescence" (1997) faz uma importante contribuição no sentido da importância do processo de julgamento dos jovens criminosos.

2. Desenvolvi estas idéias no trabalho "Instituição e violência. Violência nas instituições".

3. É a forma com a qual se designa o jovem que comete atos infracionais, a partir da vigência do ECA-Estatuto da Criança e do Adolescente. 


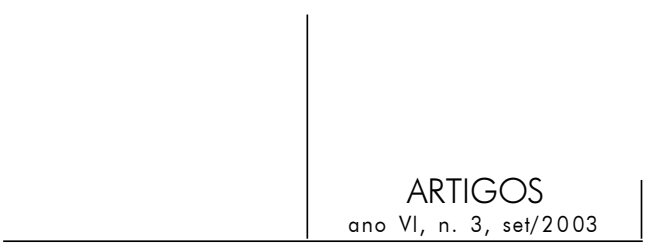

Constata-se nesses jovens uma falta de referências, tanto externas quanto internas, que tornavam difícil sua inscrição social através de uma história pessoal, familiar, social, de um passado, de um futuro. O estudo dos testes projetivos e das entrevistas, mostra um fracasso na representação das imagens parentais. (p. 122, tradução minha)

A autora segue analisando como nesses casos fica patente a ausência da função paterna e a característica de mães que remetem ora a um vazio (a "Mãe Morta" evocada por Green [1988, p. 247]) ora à imagem arcaica da mãe todo poderosa, fusional e ameaçadora. Mas o fundamental desse trabalho é apontar como no processo de julgamento do jovem criminoso lhe é dada a oportunidade de colocar em palavras a sua história, a sua relação com a vítima, refletir sobre a passagem ao ato. Instaura-se, enfim um rito iniciático onde o sujeito pode interrogar-se sobre si próprio, viver a culpa, responsabilizar-se e talvez assim deixar de ser vítima, submetido a um Outro insuportável. A importância da função das palavras aqui se coloca ao se reconhecer a expressão de um sujeito que sofre e pede reconhecimento, mesmo que seja para pagar a sua culpa. Aliás, como ensina Freud (1916), os crimes muitas vezes são cometidos para aliviar o sentimento de culpa intenso provocado justamente pelas moções pulsionais relativas essencialmente ao complexo edípico. Importante notar que a expressão Adolescentes em conflito com a lei, já propõe um engajamento do social frente a um Eu em revolução. "É na medida onde não houve castração no seio da família que o jovem vai provocar de modo concreto o bastão da polícia", aponta Melman ao falar de delinqüência (1992, p. 46).

\section{Desamparo e violência: desafios para o jovem}

Com certeza não se trata de defender o bastão de polícia quando se fala da falta da lei, analisando-se o declínio da Função Paterna como responsável pelo desamparo do sujeito contemporâneo. Mas como entender as vicissitudes edípicas e o jogo da Castração no atual cenário? Sabe-se que o regulador social contemporâneo passa muito mais pela transmissão de uma promessa de gozo do que pela consciência da dívida, do dever para com as gerações passadas, como era na sociedade tradicional. Aí se colocam sérias dificuldades para a elaboração da castração. Como organizar o narcisismo se a castração na organização social contemporânea vai apelar para a promessa do prazer, não mais evocando o dever, nem a ameaça explícita de um pai violento, como o mito edípico costuma evocar? Pensemos em como a renúncia pulsional para o jovem 


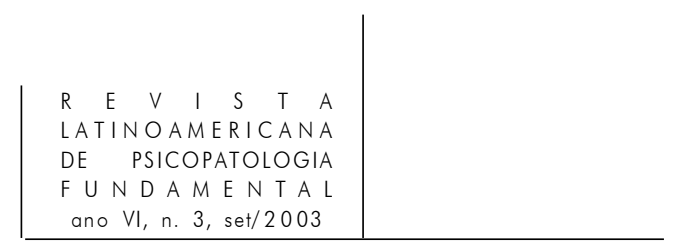

está muito mais dificultada, hoje em dia: ele pode e deve escolher o que quiser, seja em termos profissionais, seja nos valores pessoais, já que a família "deve" deixá-lo livre para escolher, não impondo sua própria referência. $\mathrm{O}$ adolescente deve, no mínimo, ser feliz, bonito, com o corpo perfeito e, para tal, deve consumir os objetos, as dietas, os exercícios que são incessantemente oferecidos no mercado. A permissividade contemporânea frente à sexualidade, ao mesmo tempo que lhe autoriza todas as possibilidades de vivência e satisfação sexual, acaba exigindo um padrão de realização sexual que aumenta em muito as exigências pulsionais. $\mathrm{O}$ adolescente fica imerso numa excitação intensa que lhe reativa o desamparo.

Claude Balier (1997), ao discutir o parricídio, vai relacioná-lo

... aos transtornos narcísicos criados pela maturação sexual, a inquietação frente à emergência das pulsões, a confrontação para uma realização daquilo que até então estava apenas no registro do fantasma, a dificuldade de reviver as perdas para encontrar novos objetos, a incerteza dos limites dentro/fora, os problemas de identidade frente às transformações corporais, etc. os conflitos dificilmente gerenciados, podem então implodir e o recurso às defesas primárias conduzir à passagem ao ato. Não é por acaso que os atos de parricídio são essencialmente cometidos na adolescência. (p. 91)

Este autor segue discutindo como o adolescente tem capacidade para ficar imerso na excitação, revelando a fragilidade de sua identidade. Ele tem a tentação de fazer desaparecer o $\mathrm{Eu}$, renunciando a seu estatuto de sujeito. O fenômeno de drogadição, típico dessa fase, explicita essa tendência. Isto revela uma tentação a manter a relação fusional primitiva com a mãe, o estado de passivação, como apresenta Green (1990), o qual oferece toda a possibilidade para o indivíduo poupar-se do movimento doloroso da separação que conduz à afirmação de identidade. O fenômeno das gangues, ou mesmo das "tribos" não necessariamente violentas, tão característico da adolescência, expressa claramente essa tendência que nada mais é do que uma busca massiva de indiferenciação - roupas, vocabulário, gestuário uniformes. O jovem aí encontra um mecanismo de, na ilusão identificatória, escapar à angústia do ser ou não ser, ou seja, da sua emergência enquanto sujeito em oposição ao outro.

Em "Psicologia das massas e análise do eu" (1921), Freud fala do grande gozo de se abandonar sem reservas, misturando-se à massa, como forma de perder o sentimento de seu próprio limite individual, e fundir-se ao imaginário de uma potência ilimitada na submissão a uma influência fascinante. $\mathrm{O}$ sujeito fica, assim, estruturalmente hipnotizado pela figura do líder "despótico, brutal e terrível". É o fascínio pelo poder do pai primitivo, todo-poderoso, que reúne os indivíduos alienados na massa, concentrando os movimentos pulsionais violentos. 


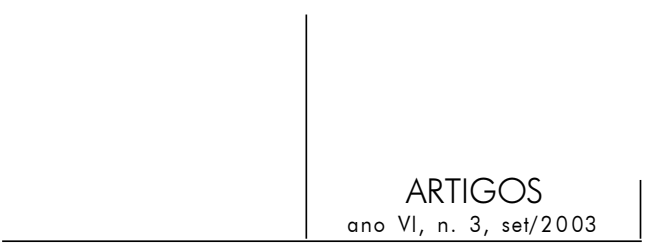

Ou seja, o fenômeno de gangue garante que o jovem fique protegido de seus votos de morte, e organize o seu desamparo que tão fortemente é suscitado na revivência edípica que esta fase retoma, principalmente se o pai faltou na sua função de simbolizar a lei.

É possível entender, então, como o jovem pode encontrar na gangue, na tribo dos "manos" um apoio para seu drama de subjetivação, para sua luta pessoal na busca do pai ideal que possa "ser morto" e viver um luto que permite identificação. Maria Rita Kehl apresenta um trabalho - "A fratria órfã" (2000) em que analisa os grupos dos "manos" jovens da periferia de São Paulo, admiradores de rap. Kehl propõe que a aliança fraterna pode possibilitar que os sujeitos explorem e ampliem suas margens relativizando o discurso da autoridade encarnado pela figura do pai real. É interessante considerar esta análise como alternativa à tão insistente constatação do declínio da função paterna.

O apelo ao reconhecimento é geralmente endereçado ao pai. O irmão, o semelhante, será destinatário deste apelo apenas quando o pai dá as costas? Penso que não; o reconhecimento paterno, fundamental para que o sujeito constitua uma certeza imaginária sobre "quem ele é" (desejo do pai) pode gerar também um aprisionamento narcísico. (p. 227)

Contudo, é fundamental considerar a posição dos adultos nessa situação, senão a violência em ato será a única saída.

A violência seria, então, aquela da fusão dos indivíduos na massa, mas também, de forma oposta, aquela do estouro dessa fusão na angústia do pânico que acontece, diz Freud, quando o líder da massa desaparece ou não mais é reconhecido, isto é, quando naufraga a autoridade paterna. É então o "sujeito do eu" que faz estruturalmente falta, sendo que anteriormente era investido como objeto. Sobra aí o ódio, o ódio pelo objeto. Nos fenômenos de violência muitos adolescentes põem em cena uma destrutividade como que para constituir um objeto no ódio, argumentando a partir das carências objetais que pontuaram sua história. (Richard, 1997, p. 63)

O manejo da violência na adolescência, portanto, não é privilégio da sociedade contemporânea. Esse conflito já aparece nas concepções míticas sobre a fundação cultural da civilização humana, na constituição da identidade de um indivíduo na cultura - o tema do herói, os rituais de iniciação, etc. Não há como negar que todas essas configurações apontam para o dilema entre, de um lado, afastar-se do fascínio da indiferenciação, do prazer nirvânico e da ausência de conflito - o Princípio Narcísico por excelência - e, de outro, poder enfrentar o desamparo. Isto vem à tona quando se é defrontado com as faltas, falhas, incertezas na perda de um pai protetor, e/ou com a violência interna que quer afastar e destruir esse "pai”, obstáculo para o gozo eterno. Mas para isso também é 


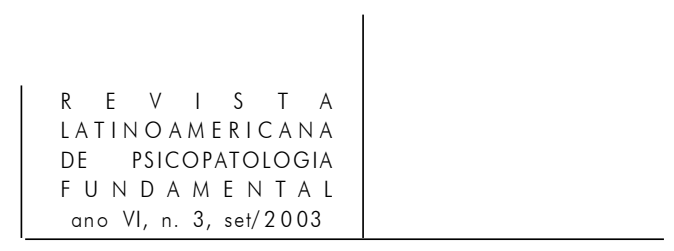

preciso um pai que assuma o ideal de força, que facilite a identificação com ele que, no fundo, traduz o ideal social, como aponta a tradição psicanalítica.

\section{Impasses contemporâneos}

Neste ponto, temos que pensar o que se passa na contemporaneidade. Será que esse "pai" tem suportado os ataques de seus filhos, mantendo-se vivo e forte, apesar de seu envelhecimento? Envelhecimento este que se constitui num fato com o qual o jovem se depara e que, de alguma forma, permite-lhe pensar em algum dia assumir o lugar do pai? Embora os adultos tenham que estar presentes, mantendo-se vivos e sustentando a tentativa de destruição que os filhos lhes imputam, eles não podem negar a morte e, sim, autorizar que os filhos mantenham a continuidade da vida, vivam sua sexualidade e potência. Winnicott (1975) aborda essa questão, lembrando que se trata sempre de uma questão de morte na adolescência, e que a melhor forma que os adultos têm de ajudá-los (aos jovens) é sobrevivendo. Neste aspecto, é importante analisar como a questão do envelhecimento e, conseqüentemente, da morte, nos dias atuais, vem sendo negada: as limitações da potência sexual são contornadas ou adiadas (Viagra, por exemplo). Métodos de rejuvenescimento permitem que os adultos se ocupem incessantemente de sua afirmação identitária. Estabelece-se assim uma situação paradoxal: de um lado, os adultos poderiam, com essas conquistas, sentir-se menos ameaçados, deixando mais espaço para o jovem buscar suas referências e diminuindo o jogo de hostilidade entre eles; de outro, se deixam os jovens sozinhos para fazerem "o que quiserem" para cumprirem o ideal social de beleza e felicidade, esses adultos lançam os jovens ao desamparo frente à violência das pulsões da puberdade porque estão eles próprios adultos comprometidos com seu narcisismo.

Soma-se a isso a falta de alternativas que a sociedade contemporânea apresenta no sentido de organizar rituais de iniciação e de exercício de poder, culturalmente aceitos. Existem poucas oportunidades de organização social para o enfrentamento da tempestade da puberdade. Carecem os anteparos que façam frente a essa energia, uma oposição que valorize e enfrente o desafio colocado pelo adolescente que luta para ser reconhecido. Os pais, na realidade, fogem da dialética "ou eu/ou o outro" ao evocarem o mote do "você é quem sabe de sua vida" sob pretexto de não querer frustrar ou violentar a individualidade do filho. Quem sabe não se esteja reeditando de forma aparentemente menos cruel (é "politicamente correto" não apelar para a violência) o mito de Cronos que devorava seus próprios filhos assim que nasciam, como forma de manter a 


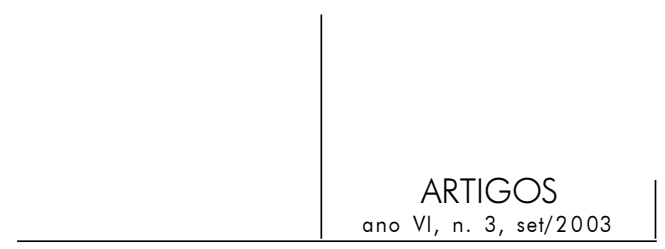

eternidade e a potência absoluta. "Pais e filhos, um para o outro, representam a morte. Quero matar meus pais porque eles querem me impedir de viver, e também porque os vejo velhos e mortais e não quero me tornar como eles. Quero matar meus filhos porque sou mais velho que eles, porque eles me tornam velho e pretendem viver depois de mim, no meu lugar" (Reyes, p. 57).

$\mathrm{O}$ que se tem visto são adultos que não conseguem se fazer presentes e fazer frente à tentativa de destruição, sendo assim, a rigor, um suporte da violência juvenil, por negar sua própria violência, já que sustentam sua potência imaginária numa figura amável e condescendente. No entanto, conhecemos bem o que sustenta o poder - a violência.

Esses adultos estão, no fundo, exercendo o que chamei de Violência Branca ${ }^{4}$ ao considerar o jovem um “aborrescente". Se aborrece, então é melhor ignorálo, afastar-se dele, poupar-se do embate que ele propõe, desviar o olhar desse corpo que pulsa, que insiste em transbordar de sexualidade quer seja nas belas formas da mulher modelo ou do jovem atleta, quer seja nas formas desajeitadas e feias (espinhas, gordura, etc.). Os infindáveis questionamentos carregados de revolta e raiva, aliados à imagem de um corpo jovem pleno de erotismo e potência criativa se tornam insuportáveis para um adulto que também vive sob a égide da busca do prazer incessante e da obsessão pela imagem perfeita. Lembro que o princípio da submissão a uma ordem dada, por exemplo, o da sucessão entre as gerações e o peso da dívida entre elas, não é o norteador da sociedade contemporânea. Ao contrário, os filhos é que deveriam ser felizes e livres para garantir o narcisismo dos pais. Não é difícil entender, então, como o adulto poupa-se de enfrentar sua própria violência, que é reativada nesse encontro com os adolescentes ao considerá-los apenas "aborrescentes" e por isso não merecerem controle e cuidados. Ao contrário, o espelho se inverte e o adulto inveja o espetáculo que o adolescente produz, abandonando-o ao seu próprio destino heróico. Mas de herói a vilão os passos podem ser curtos. E se há excessos, não se hesita em condenar os jovens. Violência crescente são os excessos da juventude malcriada, audaciosa, exigente e intolerante. A transgressão não pode ser reconhecida, já que os limites não existiam e as proibições eram vagas.

4. Conceito desenvolvido no livro Violências. 


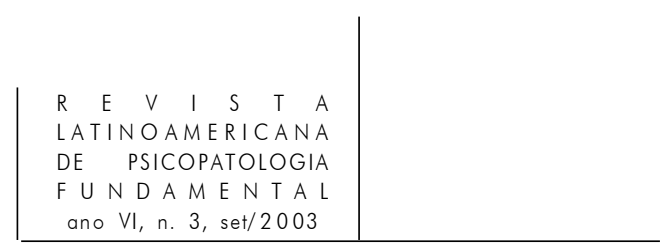

Adolescente: o estrangeiro contemporâneo

Para concluir, gostaria de fazer uma aproximação do lugar do adolescente com a do estrangeiro. O social sempre encontrou formas de exterminar o estrangeiro ou de colocá-lo no lugar de exótico como aquele que representa e atua tudo aquilo que a cultura de dada sociedade reprime. A noção do "estranho" (unheimlich) que Freud desenvolve em relação ao psiquismo também trabalha essa questão: "Na realidade, não é nada de novo nem de estrangeiro, é algo que muito tempo atrás foi familiar à vida psíquica e se tornou estrangeiro a ela pela repressão" (1919b, p. 258).

Penso que, hoje, o adolescente pode estar ocupando o lugar do estrangeiro, tanto nos seus aspectos idealizados quanto execrados. Se ele não está nos fronts de guerra contra os "maus estrangeiros", então deve ocupar o lugar das rebeliões da Febem, transfigurando-se no incendiário, no perigoso, justificando seu extermínio ou controle coercitivo que abate seu corpo e identidade. Rememorese as muitas cenas televisionadas das interferências das tropas de choque policiais na Febem, expondo, em pelotões, seus jovens de corpo nu. Evocam-se cenários de guerra, cenários de pré-fuzilamento.

Nesse contexto, quem é violento? Qual é o apaziguamento procurado? Em nome do que e de quem? Em nome de poupar os adultos, que até então invejavam a capacidade desses jovens de gozar, de lutar, de expressar seu descontentamento em protestos violentos, de buscar o prazer de forma incessante através do consumo de grifes, drogas, que buscam realizar a promessa de um mundo sem conflitos e sofrimento. Em nome, também, de poupar uma sociedade que exclui grande parcela de sua população dos direitos mínimos de cidadania e que acena com promessas ilusórias de realização, desde que no fundo se seja capaz de consumir. Os meios para isso são discutíveis. A família que deveria ter servido de referência está desestruturada, não "foi capaz", ou melhor, não encontrou na sociedade espaço para garantir o sustento dos filhos, a sua permanência na escola (que não dispõe de vagas suficientes), o seu acesso a lazer e cultura, sem falar na assistência à saúde. Tantas vezes, nas classes baixas, são as crianças as responsáveis pelo sustento das famílias mendigando nas ruas e sendo exploradas pelo trabalho infantil, ou sendo usadas no tráfico de drogas, aproveitando-se de sua inimputabilidade. Os equipamentos sociais que deveriam assistir a infância e se complementar à família falham, e acabam reproduzindo uma violência, a que chamei de branca, ao evocar que numa sociedade livre e democrática, os indivíduos que tiveram vontade poderiam ter encontrado formas de se realizar.

5. Lembro que a palavra infantaria - os que estão na frente dos fronts - vem de infans. 


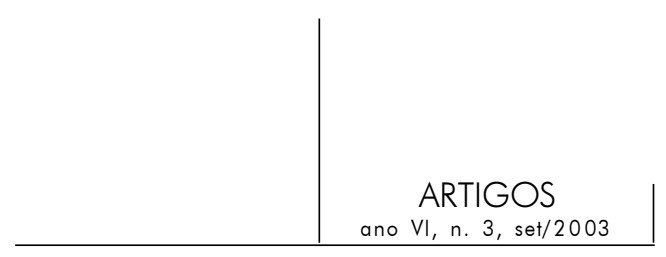

O adolescente, como se procurou evidenciar, está em busca de filiação e de reconhecimento, tentando encontrar desesperadamente no social, o lugar que lhe foi prometido, acenado, vendido, e que, em tantos casos, está tão inacessível. Volto a lembrar Winnicott (1987), que nos ensina como nas condutas anti-sociais estão os sinais de esperança, os gritos de socorro - e tantas vezes, diria eu, a denúncia de uma impostura.

Assim, depois de terem gozado junto aos adolescentes, é melhor para os adultos pensarem que, na verdade, esses adolescentes são violentos. Se eles não foram capazes de aproveitar todas as oportunidades, e já que vivem como adultos, que respondam pelos seus atos longe de nós - que sejam encarcerados.

Enfim, a adolescência nos põe face a face ao mal-estar. Apesar da ciência, da psicologia, das pedagogias, estamos, como Freud bem já denunciava, no eterno impasse da problemática relação do indivíduo com o grupo, no que diz respeito à capacidade de regulamentar a hostilidade e o ódio na relação do indivíduo com o outro. A busca da lei - os rigorosos rituais iniciáticos das sociedades primitivas, a justiça dos direitos previstos nos códigos contemporâneos, como o ECA -, que certamente organiza os restos de violência dos encontros humanos, nada mais faz do que tentar sempre reencontrar um Pai protetor, ideal, que garantiria a condição do sujeito ser amado, reconhecido - ser, quem sabe, único.

Não esqueçamos que Freud é veemente em afirmar o mal-estar, e que a violência não cessa de retornar apesar dos esforços da civilização em contê-la e organizá-la. Ele não concebe o psiquismo sem o dualismo pulsional, ou seja, o imbricamento de Eros e Tânatos, as forças de vida e morte que impulsionam os sujeitos a se encontrar, lutar, amar, transgredir, destruir e construir.

Adolescência: violenta e apaixonante condição humana. Vamos enfrentá-la.

\section{Referências}

BALIER, C. Analyse psichopathologique des comportements violents. In: L'ilégitime violence. Ramonville Saint-Agne: Érès, 1997, p. 79-93.

Bergeret, J. La violence fondamentale. Paris: Dunod, 1995.

Berlinck, M. T. O que é psicopatologia fundamental. Revista Latinoamericana de Psicopatologia Fundamental, n. 1, v. I, p. 46-59, mar/1998.

Relatório de atividades 1995-1997 do Laboratório de Psicopatologia Fundamental do Programa de Estudos Pós-Graduados em Psicologia Clínica da PUC-SP. São Paulo, s/d.

Birraux, A. Violence à l'adolescence et clivage du moi. In: L'ilégitime violence. Ramonville Saint-Agne: Érès, 1997, p. 131-44.

Couraud, S. L'acte criminel à l'adolescence. In: MARTy, F. (org.). L'illegitime violence. Ramonville Saint-Agne: Érès, 1997, p. 111-28. 


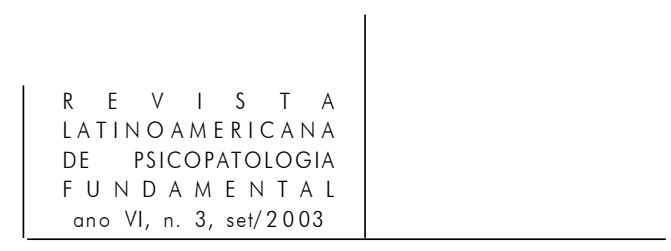

EnRiQuez, E. Da horda ao Estado. Rio de Janeiro: Zahar, 1999.

Um mundo sem transgressão. In: Plastino, C.A. (org.). Transgressões. Rio de Janeiro: Contracapa, 2002, p. 113-34.

Freud, S. Edição Standard Brasileira das Obras Completas de Sigmund Freud. Rio de Janeiro: Imago, 1996.

(1915). O instinto e suas vicissitudes. In: ESB. Op. cit., p. 137-68. v. XIV.

(1919). O estranho. In: ESB. Op. cit., p. 235-71. v. XVI.

(1916). Criminosos em conseqüência de um sentimento de culpa. In: ESB. Op. cit., p. 351-81. v. XIV.

(1921). Psicologia das massas e análise do eu. In: ESB. Op. cit., p. 79-154. v. XVIII.

(1933). Por que a guerra? In: ESB. Op. cit., p. 191-208. v. XXII.

GREen, A. Narcisismo de vida, narcisismo de morte. São Paulo: Escuta, 1988.

Passions et destins des passions. In: La folie privée. Paris: Gallimard, 1990.

Hanns, L. Dicionário comentado do alemão de Freud. Rio de Janeiro: Imago, 1996.

KeHL, M. R. A fratria órfã. In: KeHL, M. R. (org.). Função fraterna. Rio de Janeiro: Relume-Dumará, 2000, p. 209-44.

Jeammet, P. Destins de la violence in Coloque de Monaco. Journal de Psychanalyse de l'enfant, n. 18, Paris, Bayard, 1995.

MARIN, I. S. K. Instituição e violência, violência nas instituições. In: LevisKy, D. (org.). Adolescência pelos caminhos da violência. São Paulo: Casa do Psicólogo, 1998. Violências. São Paulo: Escuta, 2002.

MARTY, F. Violences à l'adolescence. In: L'illegitime violence. Ramonville Saint-Agne: Érès, 1997, p. 7-17.

Melman, C. Alcoolismo, delinqüência, toxicomania. Uma outra forma de gozar. São Paulo: Escuta, 1992.

Reyes, A. La dévoration. In: Danziger, C. Violence des familles, maladie d'amour, Paris: Autrement, 1997, p. 50-61.

RICHARD, F. Violence sacrificielle et pulsion de mort à l'adolescence. In: L'Illegitime violence. Ramonville Saint-Agne: Érès, 1997, p. 47-63.

Toubiane, E. L'héritage: une pas si belle affaire que ça. In: Violence des familles: maladie d'amour. Paris: Ed. Autrement, n. 168, 1997. Collection Mutations.

WinNicotT, D. W. O brincar e a realidade. Rio de Janeiro: Imago, 1975. Privação e delinqüência. São Paulo: Martins Fontes, 1987.

Zygouris, R. Pulsões de vida. São Paulo: Escuta, 1999. 
Este artículo discute cómo la comprensión del proceso de subjetivación del adolescente trae elementos preciosos para la problemática de la trasgresión y la violencia que, a su vez, son condición para la constitución subjetiva así como de factores de transformación o de mantenimiento del orden social.

Palabras claves: Violencia, trasgresión, adolescencia, pulsión, psicoanálisis, psicopatología fundamental

Cet article examine comment la compréhension du processus de subjectivisation de l'adolescent apporte des éléments précieux pour la problématisation de la transgression et de la violence qui, pour leur part, sont une condition pour la constitution subjective, tout comme des facteurs de transformation ou de maintien de l'ordre social.

Mots clés: Violence, transgression, adolescence, pulsion, psychanalyse, psychopathologie fondamentale

This article discusses how an understanding of the process of subjectivation in adolescents brings up important points for problematizing transgression and violence. These aspects, in turn, are conditions for subjective constitution as well as factors for transforming or maintaining the social order.

Key words: Violence, transgression, adolescence, drive, psychoanalysis, fundamental psychopathology 